\title{
European Multiconfessionalism and the English Toleration Controversy, 1640-1660
}

\author{
Professor John Coffey (University of Leicester)
}

Published in Thomas Max Safley, ed., A Companion to Multiconfessionalism in the Early Modern World (Brill, 2011), 340-64.

Old-fashioned histories of toleration typically assumed that 'ideas rule the world'. ${ }^{1}$ As a result, they gave pride of place to a heroic line of progressive thinkers from Castellio to Voltaire who condemned persecution and argued for intellectual and religious freedom. In recent years, however, historians of toleration have started to 'play down the power of ideas'. ${ }^{2}$ Intellectual history, which was once central to accounts of 'the rise of toleration', is now being displaced by the political and (especially) social history of religious coexistence. ${ }^{3}$ This historiographical shift is an important corrective to the overly idealist (and idealised) scholarship of earlier generations, for it gives us a sophisticated insight into the actual practice of tolerance and intolerance in states and communities across Europe. However, it raises questions. How do the old and the new history of toleration relate to each other, if at all. Is intellectual history now passé? Or should we be exploring the interface between early modern practice and early modern theory? ${ }^{4}$ Judith Pollman has suggested that this is the way forward. She wonders if the practice of coexistence was 'the catalyst for new ideas on religious uniformity', and whether 'the everyday experience of living with pluralism' caused 'an intellectual orientation away from the Augustinian imperative compelle intrare ${ }^{\prime 5}$

In this essay, I want to address such questions and bridge the gap between theory and practice by considering what participants in the English toleration controversy had to say about the multiconfessional polities of continental Europe. Surprisingly, perhaps, this has received little attention from historians. It is a commonplace that the Dutch republic was exhibit $A$ for tolerationists, and some historians think that pragmatic arguments for toleration based on 'reason of state' were more persuasive and important than philosophical or theological arguments. ${ }^{6}$ Yet studies of tolerationist texts tend to concentrate on the latter, and there has been no sustained examination of English appeals to European religious diversity. By focussing on England's first major

\footnotetext{
${ }^{1}$ Perez Zagorin says just that in How the Idea of Toleration Came to the West (Princeton: Princeton University Press, 2003), p. 12.

2 The phrase is Alexandra Walsham's in Charitable Hatred: Tolerance and Intolerance in England, 1500-1700 (Manchester: Manchester University Press, 2006), p. 8. Walsham herself is ambivalent on the power of ideas. On the one hand, she argues that 'the early modern ideology of religious intolerance...exerted enormous influence at the end of the seventeenth century, no less than at the beginning of the sixteenth' (p. 49). The case for toleration, by contrast, is assumed to be largely ineffectual 'outside the circles of the literate intellectuals who articulated it' (p. 238).

${ }^{3}$ The best synthesis of this new scholarship is Benjamin Kaplan, Divided by Faith: Religious Conflict and the Practice of Toleration in Early Modern Europe (Cambridge, MA: Harvard University Press, 2007).

${ }^{4}$ For further reflections on the historiography see my 'Milton, Locke and the new history of toleration', Modern Intellectual History, 5 (2008), 619-32.

5 Judith Pollman, 'Getting along', History Workshop Journal, 64 (2007), 423.

${ }^{6}$ Henry Kamen asserts that 'Trade was usually a stronger argument than religion'. See Kamen, The Rise of Toleration (London: Weidenfeld and Nicholson, 1967), pp. 224-27, quotation at p. 224. For a theoretical defence of the priority of political (and economic) factors see Anthony Gill, The Political Origins of Religious Liberty (Cambridge: CUP, 2008).
} 
toleration controversy - the one that raged during the Puritan Revolution of the mid-seventeenth century - we should be able to explore the uses of European multiconfessionalism. ${ }^{7}$

\section{European Example in English Debate}

Perhaps the first thing to note is how little English tolerationists referred to the multiconfessional polities of continental Europe. At its debates over toleration in Whitehall in December 1648, the New Model Army and its clerical supporters concentrated overwhelmingly on philosophical, theological and biblical arguments, and only one short reference was made to the Dutch practice of toleration. ${ }^{8}$ In a series of pamphlets against religious uniformity, the Leveller William Walwyn made only the briefest of comments about pluralism in the Netherlands and elsewhere. ${ }^{9}$ In his lengthy treatise, The Bloudy Tenent of Persecution, Roger Williams made just a single fleeting reference to toleration in the United Provinces. The great bulk of this work was devoted to deconstructing the biblical arguments for uniformity. As he explained, 'so great a waeight of this controversie lyes upon this president of the Old Testament ${ }^{\prime} .^{10}$

Anti-tolerationists, like the Covenanter Samuel Rutherford, shared the view that biblical and theological issues were at the heart of the controversy. Rutherford's A Free Disputation against Pretended Liberty of Conscience (1649), has been described by Owen Chadwick as 'the ablest defence of persecution in the seventeenth-century, ${ }^{11}$ but in a treatise of more than 400 pages, Rutherford never so much as mentioned multiconfessionalism in contemporary Europe. By contrast, he devoted entire chapters to the exegesis of specific biblical passages, like the Parable of the Wheat and the Tares. In seventeenth-century Christendom, as in twenty-first century Islam, much hung on the interpretation of sacred texts. ${ }^{12}$ Toleration controversies involved a battle for the Bible. Because this was a battle no one could afford to lose, it absorbed far more polemical energy than the race to find current examples of successful (or unsuccessful) regimes of toleration. Most advocates of toleration mentioned European religious pluralism only in passing - it was not a major plank of their case, and no one elaborated at length on Dutch, French or Central and Eastern European arrangements.

\footnotetext{
${ }^{7}$ For overviews of this controversy, see W. K. Jordan, The Development of Religious Toleration in England, 4 vols (Cambridge, MA: Harvard University Press, 1932-40), vols. III and IV; B. Worden, 'Toleration and the Cromwellian Protectorate', in W. J. Sheils, Persecution and Toleration (Oxford: Basil Blackwell, 1984), 199233; Andrew Murphy, Conscience and Community: Revisiting Toleration and Religious Dissent in Early Modern England and America (Unversity Park, PA: Pennsylvania State University Press, 2001), ch. 3; Sebastian Barteleit, Toleranz und Irenik: Politisch-Religiose Grenzsetzungen im England der 1650er Jahre (Mainz: Verlag Philipp von Zabern, 2003); Zagorin, How the Idea of Toleration Came to the West, ch. 6; John Coffey, 'The toleration controversy', in C. Durston and J. Maltby, eds, Religion in Revolutionary England (Manchester University Press, 2006), ch. 2. None of these accounts offers an extended analysis of how tolerationists and their critics argued over European multiconfessionalism.

${ }^{8}$ A. S. P. Woodhouse, ed., Puritanism and Liberty: Being the Army Debates (1647-49) from the Clarke Manuscripts (London: J. M. Dent, 1992), pp. 125-78; reference to the Netherlands on p. 138.

${ }_{9}^{9}$ The Writings of William Walwyn, ed. J. R. McMichael and B. Taft (Athens, GA: University of Georgia Press, 1986), pp. 57, 114, 161.

${ }^{10}$ [Roger Williams], The Bloudy Tenent of Persecution (1644), pp. 160, 179. As we shall see, Williams made more reference to the Netherlands in later writings.

${ }^{11}$ Owen Chadwick, The Reformation (Harmondsworth: Penguin, 1964), p.403.

${ }^{12}$ For the scriptural character of modern Islamic debates over blasphemy law see Abdullah Saeed and Hassan Saeed, Freedom of Religion, Apostasy and Islam (Aldershot: Ashgate, 2004).
} 
But it would be a mistake to dismiss tolerationist pamphleteers as abstract theorists with little interest in practicalities of power. On the contrary, they were often immersed in local and national politics. ${ }^{13}$ Throughout the 1640 s, the merchant William Walwyn was an activist for the Parliamentarians, the Independents and then the Levellers. Sir Simonds D'Ewes was a member of Parliament. Sir Henry Vane the younger had been the Governor of Massachusetts during the Antinomian Controversy, and though that turned out badly, he re-emerged in the 1640 s as one of the most capable administrators in the House of Commons, playing a key role in running the navy. ${ }^{14}$ Vane's friend Roger Williams was in London to gain a charter for the fledgling colony of Rhode Island and exploited his high level connections to outmanoeuvre Massachusetts. ${ }^{15}$ John Goodwin was a London pastor, but he and his congregation were in the thick of City politics, supporting the Independent faction through printing, petitioning, spying and sitting on key bodies like Common Council and the Militia Committee. ${ }^{16}$ Henry Robinson was a merchant, a member of the Hartlib circle, and an enthusiastic promoter of practical schemes of improvement. ${ }^{17}$

As practical men who wished to get things done, these tolerationists could not afford to ignore the standard early modern assumption that religious unity was fundamental to political stability. ${ }^{18}$ Protestant England was a confessional state, and most early Stuart commentators agreed that withdrawal from the national church was effectively withdrawal from the commonwealth itself. 'Religion being the chief band of human society', wrote Sir Francis Bacon, 'it is a happy thing when itself is well contained within the true band of unity'. ${ }^{19}$ The membership of church and state was conceived as coextensive. 'There is not any man of the Church of England', wrote Richard Hooker, 'but the same man is also a member of the commonwealth; nor any man a member of the commonwealth, which is not also of the Church of England' ${ }^{20}$ The Puritan divines who preached before Parliament in the 1640 s echoed this sentiment. 'Schism in the church, begets a Schism in the State', averred Matthew Newcomen. 'Divisions whether they be Ecclesiasticall or Politicall in Kingdomes, Cities and Families, are infallible causes of ruin', claimed the Presbyterian Edmund Calamy. ${ }^{21}$

One way to respond to this charge was to turn it around, by blaming intolerant regimes for fomenting religious wars. The Leveller, Richard Overton, produced a satirical tract purporting to describe the trial of 'Mr Persecution'. The witnesses against him included Mr Blood-of-Princes, Mr Desolate-Germany and Mr Domestick-Miseries. ${ }^{22}$ Tolerationists frequently blamed heavy-handed Laudian bishops for provoking the conflict that led to civil war. Williams called the idea of forced

\footnotetext{
${ }^{13}$ For what follows, see the Oxford Dictionary of National Biography as well as the sources listed.

${ }^{14}$ His career as a Parliamentarian politician is ably explored in V. Rowe, Sir Henry Vane the Younger: A Study in Political and Administrative History (London: Athlone Press, 1970).

${ }^{15}$ His career is best followed through The Correspondence of Roger Williams, ed. Glenn La Fantasie, 2 vols (Hanover, NH, 1988).

${ }^{16}$ See John Coffey, John Goodwin and the Puritan Revolution (Woodbridge: Boydell and Brewer, 2006).

${ }^{17}$ The fullest study of Robinson remains W. K. Jordan's Whiggish monograph, Men of Substance : A Study of the Thought of Two English Revolutionaries, Henry Parker and Henry Robinson (Chicago: University of Chicago Press, 1942).

${ }^{18}$ See Conrad Russell, 'Arguments for religious unity in England, 1530-1650', Journal of Ecclesiastical History, 18 (1967), 201-26.

${ }^{19}$ Francis Bacon, 'Of unity in religion’, Essays (London: J. M. Dent, 1992), p. 8.

${ }^{20}$ Richard Hooker, The Laws of Ecclesiastical Polity, VIII.i.2.

${ }^{21}$ Cited in an Anglican compilation of Puritan testimonies: Toleration Disapprov'd and Condemn'd (1670), pp. 43, 33.

${ }^{22}$ [Richard Overton], The Arraignement of Mr Persecution (1645), pp. 5-6.
} 
uniformity a 'State-killing doctrine'. ${ }^{23}$ Another pamphleteer asked: 'What blood, confusions, strifes and contentions, hath compulsion brought forth? All wars, tumults, almost every where, have arisen from this spirit of violence and compulsion. Hence the Papist persecutes the Protestant, and the Protestant the Papist. Hence the Turkes opposeth the Christian, the Christian the Turke'. ${ }^{24}$

But pointing to the political chaos wrought by religious coercion was insufficient. Tolerationists also needed to show that their proposals were compatible with stable and flourishing states. Thus among his witnesses against Mr Persecution, Overton included Mr Unity-of-Kingdomes, Mr NationalStrength, Mr Setled Peace, Mr Humaine Society, Mr Publique Good and Mr National-Wealth. The case against the accused was forcefully put by Mr State Policie: 'were the devouring principle of persecution weeded out from betwixt all Religion, they might all enjoy their publike safety to the generall enlargement and strengthening of politike power... ${ }^{25}$ Arguments from 'reason of state' or national interest were one important component of the case for toleration.

Alongside general arguments for the viability of pluralistic states, tolerationists offered concrete examples. Often they pointed to ancient cases of peaceful coexistence. The Hebrew patriarchs had lived peacefully among Egyptians, Philistines and Hittites. The Jewish nation at the time of Christ had accommodated various sects: Pharisees, Sadducees, Essenes. The Roman Empire was religiously pluralistic, and it was under this regime that Christianity first thrived. ${ }^{26}$

But advocates of toleration also turned to contemporary examples. It was here that multiconfessional polities became very pertinent. A number of writers suggested that Christian Europe would do well to learn from the Ottoman Turks, who had found ways to peacefully accommodate religious difference. ${ }^{27}$ But it was more common to cite the experience of Christian states. Henry Robinson covered all angles, pointing to the religious freedom granted to minorities by the United Provinces, 'a Popish French King', and 'an unbelieving Turk'. ${ }^{28}$ Roger Williams listed 'the Cities of Holland, Poland, or Turkie' as places where there was 'some freedome', and where adherents of different religions 'were commingled in civil cohabitation and commerce together'. ${ }^{29}$ The Baptist Christopher Blackwood noted that Poland and Holland permitted diversity of religion 'with no small benefit to the publike peace'. ${ }^{30}$ When the Scottish Presbyterian Adam Stewart claimed that there was 'no State in Christendome, where there is one onely Religion established, that will admit the publick exercise of any other', John Goodwin retorted that this was 'manifestly untrue, as is notoriously knowne in France, the Low Countries $\& c^{\prime}{ }^{31}$ The author of Liberty of Conscience Asserted (1649) cited the tolerance of religious dissenters in Holland, France, Germany and Switzerland, adding that the Dutch Reformed tolerated the idolatrous inhabitants of their

\footnotetext{
${ }^{23}$ Roger Williams, Mr Cottons Letter...Examined and Answered (1644), p. 6.

${ }^{24}$ Freedom of Religious Worship (1654), p. 17.

${ }^{25}$ Overton, The Arraignement of Mr Persecution, pp. 4-5, 29.

${ }^{26}$ See for example, Overton, The Arraignement of Mr Persecution, p. 31; Samuel Richardson, The Necessity of Toleration (1647), p. 20.

${ }^{27}$ See Nabil Matar, Islam in Britain, 1558-1685 (Cambridge: CUP, 1998), pp. 103-07; Nabil Matar, 'The toleration of Muslims in Renaissance England', in John Christian Laursen, ed., Religious Toleration: 'The Variety of Rites' from Cyrus to Defoe (London: Macmillan Press, 1999), pp. 129-31; Gerald Maclean, 'Milton, Islam and the Ottomans', in Sharon Achinstein and Elizabeth Sauer, eds, Milton and Toleration (Oxford: OUP, 2007), pp. 285-90.

${ }^{28}$ [Henry Robinson], John the Baptist, or Liberty of Conscience (1644), sig. A4r.

${ }^{29}$ Williams, The Bloudy Tenent Yet More Bloudy (1652), p. 166.

${ }^{30}$ Christopher Blackwood, The Storming of Antichrist (1644), p. 17.

${ }^{31}$ John Goodwin, M.S. to A.S. or Liberty of Conscience (1644), p. 87. See also p. 108.
} 
colonies in the East Indies. ${ }^{32}$ In the epic parliamentary debates over the blasphemy of the Quaker James Nayler, one of the few voices raised in his defence was that of the Baptist Major-General Packer. Packer declared that the duty of Parliament was 'to give every man his native liberty, which is given in Holland, Poland, and other countries, a free exercise of their consciences'. ${ }^{33}$

Some tolerationists had first hand knowledge of these lands, and it is tempting to speculate that travel had broadened their minds. ${ }^{34}$ Sir Henry Vane and John Milton had been on the Grand Tour, but while this exposed them to a cosmopolitan humanist culture, it also cemented their lifelong hostility to Tridentine Catholicism, and their tolerationist works in this period make no admiring references to European examples. ${ }^{35}$ Henry Robinson, by contrast, did emphasise the peaceful religious diversity in other lands, something he had witnessed himself as a merchant who had worked abroad as a factor for his father. He was well informed about the scope and limits of religious tolerance in Holland, France, Spain, Italy and Turkey. Roger Williams had lived up close and personal with Native Americans, and his largely positive interactions with pagan Algonquians underpinned a sense of common humanity and mutual respect for people of other faiths. ${ }^{36}$

Even tolerationists who had no experience of foreign travel were keen to acquire information about the religious toleration practised on continental Europe. William Walwyn expressed some scorn for those who travelled abroad, but he acquired a smattering of cosmopolitan learning through vernacular translations of Montaigne and the classics and was an admirer of the Dutch. ${ }^{37}$ John Goodwin, who (as far as we know) never ventured beyond London and East Anglia, explained that he had learned about religious diversity abroad 'in report from persons of good esteem and worth, who have been ey-witnesses and diligent observers of such things, both in the Low-Countries and in France'. ${ }^{38}$

A number of writers wrote admiringly of the French example. 'States lose nothing', wrote one Independent, 'by preserving the Liberties of mens consciences'. 'In France', he continued, 'the Protestants are accounted the best Subjects, they are tolerated contrary to the publike Government of the State, yet are not inconsistent with the well being and flourishing condition of it'. ${ }^{39}$ Henry Robinson agreed. In mixed company, French Protestants were typically outnumbered by their Catholic compatriots, but the Catholics 'are so temperate and discreet, that it is held an unseemly

\footnotetext{
${ }^{32}$ Liberty of Conscience Asserted (1649), pp. 5-6.

${ }^{33}$ The Diary of Thomas Burton, ed. J. T. Rutt Esq., 4 vols (London, 1828), I, p. 100.

${ }^{34}$ For contrasting perspectives on this claim see John Christian Laursen, 'Irony and toleration: lessons from the travels of Mendes Pinto', Critical Review of International Social and Political Philosophy, 6 (2003), 21-40; James Ellison, George Sandys: Travel, Colonialism and Tolerance in the Seventeenth Century (D.S. Brewer, 2002); Joy Charnley, Pierre Bayle: Reader of Travel Literature (Verlag Peter Lang, 1998).

${ }^{35}$ See [Henry Vane Jr.] Zeal Examined (1652); John Milton, Areopagitica, A Speech of Mr John Milton for unlicens'd Printing (1644); J[ohn] M[ilton], A Treatise of Civil Power in Ecclesiastical Causes (1659). Vane, however, did think that England could emulate the Dutch republic by flourishing as a 'free state': See Diary of Thomas Burton, III, pp. 173-80.

${ }^{36}$ See Williams, A Key into the Language of America (1643). See also P. Rubertone, Grave Undertakings: Roger Williams and the Narragansett Indians (Washington, DC: Smithsonian Institution Press, 2001), and M. Nussbaum, Liberty of Conscience: In Defense of America's Tradition of Religious Equality (New York: Basic Books, 2008), ch. 2: 'Living Together: The Roots of Respect'.

${ }^{37}$ The Writings of William Walwyn, p. 50.

${ }^{38}$ John Goodwin, Innocencie and Truth Triumphing Together (1645), p. 54. See also Goodwin, Theomachia, or the Grand Imprudence of Men Fighting Against God (1644), p. 23, where he explains that he has been 'credibly informed' about the Dutch situation.

${ }^{39}$ A Moderate Answer to Mr Prins Full Reply (1645), p. 40.
} 
and uncivill part, for a Papist to aske an other what Religion he is of', lest the Protestants should feel intimidated. In England, however, it was sadly acceptable 'to reproach one an other with the nickname of Puritan or Separatist, Presbyterian or Independent'. ${ }^{40}$

The Anglican tolerationist, Jeremy Taylor, also appealed to the recent history of France in making the prudential case for a multi-confessional state: ${ }^{41}$

the experience which Christendom hath had in this last Age is Argument enough, that Toleration of differing opinions is so farre from disturbing the publick peace, or destroying the interest of Princes and Common-Wealths, that it does advantage to the publick, it secures peace...When France fought against the Huguenots, the spilling of her own blood was argument enough of the imprudence of that way of promoting Religion; but since she hath given permission to them, the world is witnesse how prosperous she hath been ever since. $^{42}$

\section{Going Dutch}

But of Europe's multiconfessional states, the Dutch republic ranked first in the estimation of English tolerationists. ${ }^{43}$ Richard Overton listed Holland, Poland and Transylvania as nations that had rejected persecution, but Holland came first, and 'Mr United Provinces' was one of Overton's chief witnesses. ${ }^{44}$ The priority of the Dutch model is not surprising. The Dutch republic was the foreign country that English tolerationists knew best. This was true in the later seventeenth century, when it was home for a time to John Locke, Gilbert Burnet and Benjamin Furly. ${ }^{45}$ In the early seventeenth century, the United Provinces was a haven for English nonconformists and dissenters, including the the first English Baptists who produced some of the pioneering tolerationist tracts in English. ${ }^{46}$ Henry Robinson had worked for nine years in the Netherlands as a merchant. Richard Overton seems to have lived there for some time too, possibly joining an Anabaptist congregation. Hugh Peter had been a chaplain and pastor in the United Provinces for several years and visited the country again in 1643 to raise funds for Parliament. ${ }^{47}$ He believed that the English needed to catch up with the Dutch

\footnotetext{
${ }^{40}$ [Henry Robinson], Liberty of Conscience (1644), pp. 40-41.

${ }^{41}$ On Anglican Royalists and toleration see G. Burgess, 'Royalism and liberty of conscience in the English Revolution', in John Morrow and Jonathan Scott, eds, Liberty, Authority, Formality: Political Ideas and Culture, 1600-1900 (Exeter: Imprint Academic, 2008), ch. 1; Nicholas McDowell, 'The ghost in the marble: Jeremy Taylor's Liberty of Prophesying (1647) and its readers', in Ariel Hessayon and Nicholas Keene, eds, Scripture and Scholarship in Early Modern England (Aldershot: Ashgate, 2006),

42 Jeremy Taylor, Liberty of Prophesying [1647] (1650 edn), p. 21.

${ }^{43}$ English admiration and emulation of the Dutch is explored by Lisa Jardine, Going Dutch : How England Plundered Holland's Glory (London: HarperPress, 2008), though she overlooks religious toleration. See also Stephen Pincus, 1688: The First Modern Revolution (New Haven, CT: Yale University Press, 2009).

${ }^{44}$ Overton, The Arraignement of Mr Persecution, pp. 12, 31, 5.

45 This continued to be true in the later seventeenth century, when leading advocates of toleration like John Locke, Benjamin Furly and Gilbert Burnet participated in tolerationist associations while living in exile in the Netherlands. See John Marshall, John Locke, Toleration and Early Enlightenment Culture (Cambridge: CUP, 2006), ch. 16.

${ }^{46}$ See Kevin Sprunger, Dutch Puritanism: A History of the English and Scottish Churches of the Netherlands in the Sixteenth and Seventeenth Centuries (Leiden: E. J. Brill, 1982); James Coggins, John Smyth's Congregation: English Separatism, Mennonite Influence and the Elect Nation (Waterloo, Ontario, 1991).

${ }^{47}$ For Peter, Overton and Robinson, see the Oxford Dictionary of National Biography.
} 
republic by imitating its policies in numerous areas. ${ }^{48}$ Roger Williams may not have been to the Netherlands, but he had learnt some Dutch (or the Dutch dialect of German) from colonists at New Amsterdam, and later passed it on to John Milton. ${ }^{49}$

For the most part, English tolerationists chose not to emphasise the limits and complexities of Dutch tolerance..$^{50}$ In some cases, that may be due to ignorance, but mostly it was because complexity did not serve polemical purposes. Henry Robinson went further than most in acknowledging the chequered history of Dutch policy, but he too accentuated the positive. He insisted (on the authority of Grotius) that during the revolt against Spain, the United Provinces had declared 'That they took not up Armes for Religion'. The Dutch Revolt was not a war of religion. Indeed, at a time when Amsterdam and other towns had been overwhelming Catholic, the states had agreed that there should be freedom of conscience for all. Later, however, in the wake of the Synod of Dort, there had been fierce repression of the Arminians, 'in some few places by the instigation of a most violent party, seconded by the Prince'. Nevertheless, the Remonstrants were 'quickly restored againe, and have now their places of publicke meetings, and greater liberty than ever', even in Amsterdam and Utrecht, where they had suffered most. Indeed, Robinson did not know of one place, or City throughout the united Provinces', where the decrees of the Synod were 'at present, coercively enforced'. To the contrary, the Dutch:

permit people of all Religions to live amongst them, and though they have continual wars with Spain, and Papists in some Towns amongst them have more liberty then in others, yet every where their freedome is great, and though in some places they are one fourth or one halfe part Papists, yet doe not the States subject themselves to be terrified or troubled with jealousies or other plots and treacheries then in punishing the authours at such times as they happen to be discovered. ${ }^{51}$

The most critical comments on the limits of Dutch generosity came from Roger Williams in The Bloudy Tenent Yet More Bloudy (1652). Here he acknowledged that toleration in the Netherlands was driven by pragmatism more than principle. 'The Politick States-men' of Holland had been 'lamentably whipt by the King of Spaines (and Gods) Scourge, Duke D'alva, into a Toleration of other mens Consciences'. Forced to build an ecumenical alliance against Spain, they then forestalled clerical criticism by providing Reformed divines with 'sure and setled Maintenance out of the States purse'. Hence, Williams wryly observed, 'the Dutch Ministers zeale is not so hot against the Toleration of Hereticks in the Civill State, as the English hath been'. Dutch tolerance owed much to 'worldly policie' and 'State-necessity'. Some had even suggested that they feared toleration in England because it would stem the influx of economically productive religious refugees. Williams hoped that England would go far beyond the 'Dutch President'. Despite learning lessons in 'their School of Warre' (the revolt against Spain), the Dutch had failed to 'learn that one poor Lesson of setting absolutely the consciences of all men free'. They had merely 'vouchsafed to the Papists and

\footnotetext{
${ }^{48}$ See Hugh Peter, Good Work for a Good Magistrate (1651), sig. A6r-v, pp. 19, 20, 22, 27, 39, 92, 102, $104-07$.

49 See Gordon Campbell and Thomas N. Corns, John Milton: Life, Work and Thought (Oxford: OUP, 2008), p. 247.

${ }^{50}$ Recent scholarship highlights these limits. See especially R. Po-Chia Hsai and Henk van Nierop, eds, Calvinism and Religious Toleration in the Dutch Golden Age (Cambridge University Press, 2002); John Marshall, John Locke, Toleration and Early Enlightenment Culture, pp. 138-93, 335-70.

${ }^{51}$ [Robinson], Liberty of Conscience, pp. 47-48.
} 
Arminians the liberty (as I may so speak) of the prison and sometimes to go abroad (as I may say) with a Keeper, $\& c^{\prime} .{ }^{52}$

Most Puritan tolerationists did not share Williams' desire to outstrip the tolerance of the Dutch. They wanted to secure liberty for all conscientious Protestants, but were much more hesitant about Jews and especially Catholics. ${ }^{53}$ The appeal of the Dutch owed much to the fact that they were a predominantly Protestant people, with a Reformed public church. The policy of Dutch magistrates seemed more directly applicable to the English situation than that of popish French kings or distant Polish noblemen. Faced by English Presbyterians agitating for a comprehensive national church, Independents could highlight the very different setup tolerated by the Dutch Reformed. As John Goodwin pointed out, the Presbyterians had sworn (in the Solemn League and Covenant) to follow 'the example of the best reformed churches', but 'the Church of Holland' was known to be 'very indulgent...to give Toleration upon Toleration, I mean to tolerate severall kinds of Religion, and Church-Government amongst them'. The Reformed Church was the public church of the Netherlands 'and is reputed Presbyteriall', but 'In severall populous towns in the Low-Countries, scarce every $5^{\text {th }}$, nay, not every $8^{\text {th }}$ person... is immembred into any of their Churches' ${ }^{54}$ The implication was clear: if the Dutch Presbyterians could be so accommodating of non-members and other congregations, why not the English?

Tolerationists insisted that the Dutch way was a godly way. Whereas Presbyterians pitted licentious Amsterdam against godly Geneva, William Dell told a very different tale of two cities. Dell asserted the spiritual credentials of Amsterdam, as a city that gave 'free passage' to the Gospel, and accused Protestant forcers of conscience of taking their cue from Rome, the capital of persecution. ${ }^{55}$ According to Roger Williams, 'the States of Holland' had learned from Christ ('the wisest Polititian that ever was') who taught that the tares should be allowed to grow alongside the wheat until the day of judgement. The Dutch 'tollerate, though not owne (as you say) the several Sects amongst them which differ from them, \& are of another conscience and worship'. ${ }^{56}$ In the 1650 s, one writer declared that he much preferred 'the free Ayre' of Holland 'where all Religions are permitted', to the enforced conformity of Puritan New England. ${ }^{57}$ For radical Independents, the Dutch republic was a model to set against Presbyterian Geneva and Congregationalist Massachusetts.

Tolerationists also suggested that Dutch tolerance had secured temporal blessings from above. Roger Willliams was convinced of it:

What was it, that within the memory of man hath so wonderfully (almost miraculously) raised and advanced from the low valleys, that poor fisher-town of Amsterdam (now one of the gallantest of the Lady Cities of the world)? I say, What was it but Mercy, Mercy which that poor Fisher-town shewed to distressed and persecuted consciences... $?^{58}$

\footnotetext{
${ }^{52}$ Williams, The Bloudy Tenent Yet More Bloudy, p. 175, sigs. Ar, Br.

53 This is especially true of the conservative Congregationalists. See Avihu Zakai, 'Religious toleration and its enemies: the Independent divines and the issue of toleration during the English Civil War', Albion, 21 (1989), 133.

${ }^{54}$ John Goodwin, Anapologesiates Antapologia (1646), p. 70; Goodwin, Theomachia, p. 23.

${ }^{55}$ Dell, Right Reformation (1646), pp. 41-42.

${ }^{56}$ Roger Williams, Queries of the Highest Consideration (1644), p. 12.

${ }^{57}$ Freedom of Religious Worship, p. 26.

${ }^{58}$ [Roger Williams], The Examiner Defended (1652), pp. 17-18.
} 
In another work, Williams expanded the point, claiming that Amsterdam had been populated by religious refugees fleeing from the town of Enchuysen, 'whose Zealous, over-zealous and furious Clergie provoke the Civil Magistrates to persecute dissenting, non conforming consciences':

This confluence of the persecuted, by Gods most gracious coming with them, drew Boats, drew Trade, drew Shipping, and that so mightily in so short a time, that Shipping, Trading, wealth, Greatnesse, Honour (almost to astonishment in the Eyes of all Europe, and the world) have appeared to fall as out of Heaven in a Crown or Garland upon the head of that poor Fisher-Town. ${ }^{59}$

The Anglo-Dutch war of 1652-54 made it more difficult to celebrate the Dutch miracle. ${ }^{60}$ Williams, who was writing in the year the war broke out, joined other Independents in accusing the Dutch of falling into pride, ingratitude and drunkenness. But with some ingenuity, he turned the conflict to his advantage by stressing that God judged nations on their treatment of the oppressed. The rise of the Dutch republic was due to its mercy, but its failure to assist the embattled godly of England would 'stain the Pride of all their rising Glory'. ${ }^{61}$

Despite the Anglo-Dutch war, tolerationists throughout the 1640s and 1650s were consistent in attributing the stability and prosperity of the Netherlands to their policy of toleration. ${ }^{62}$ The Baptist Blackwood alleged that liberty of conscience united all citizens behind the magistrates. ${ }^{63}$ John Goodwin insisted that the Dutch had never experienced any 'contentions or mischiefs' from their religious minorities. Their only real crisis (in the 1610s) came about because of quarrels among the established clergy, not the tolerated; their Presbyterians, not their Independents. ${ }^{64}$ Walwyn argued that 'the prosperity of our Neighbours in Holland' discredited the charge that religious diversity was fatal to a polity - the Dutch lived peaceably 'one amongst an other', and the Spaniard could testify that they united effectively in defence of their common liberties and their common enemies. ${ }^{65} \mathrm{At}$ the Whitehall Debates in 1648, when leading Independents allied to the New Model Army clashed about the degree of toleration to be afforded minorities, the preacher Hugh Peter attacked 'that old spirit of domination, of trampling upon your brethren'. 'Witness the country next from us', he remarked, 'that hath all the marks of a flourishing state upon it - I mean the Low Countries: they are not so against, or afraid of, this toleration' ${ }^{66}$ The Baptist John Vernon declared that English toleration should extend to 'Jews or heathens', for had not the Low Countries flourished 'ever since they suffered every man to worship according to his conscience, and even the Jews themselves to worship in their publike synagogues' ${ }^{67}$ Another radical tolerationist declared that 'The wise and Potent States of Holland ----- by long experience, have found no danger, but much increase of wealth and Trade, to accrue by the permission of all Religions' ${ }^{68}$ In the 1650 s, the republican propagandist Marchamont Nedham attacked 'Uniformity-mongers' and declared that England could learn from

\footnotetext{
${ }^{59}$ Williams The Bloudy Tenent Yet More Bloudy, sig. A4v.

${ }^{60}$ The shifts in English attitudes and policy towards the Dutch in 1650s are explored in Steven Pincus, Protestantism and the Making of English Foreign Policy, 1650-1668 (Cambridge: CUP, 1996), pp. 9-191.

${ }^{61}$ [Williams], The Examiner Defended, p. 18.

${ }^{62}$ See for example, Richardson, The Necessity of Toleration, p. 38.

63 Blackwood, The Storming of Antichrist, p. 21.

${ }^{64}$ Goodwin, Anapologesiates Antapologia, p. 115.

${ }^{65}$ The Writings of William Walwyn, pp. 114-15. See also p. 161.

${ }^{66}$ Woodhouse, ed., Puritanism and Liberty, p. 138.

${ }^{67}$ John Vernon, The Swords Abuse Asserted (1648), p. 13.

${ }^{68}$ Freedom of Religious Worship, p. 11.
} 
'the states of Holland, who by a prudent toleration of severall professions, have established themselves in such a measure of peace plenty, and liberty, as is not to be equalled by any other [nation]'. ${ }^{69}$

The most intriguing defence of Dutch pluralism was developed by Henry Robinson. In an argument reminiscent of Pascal's wager or Rawls' veil of ignorance, he suggested that one's chances of finding the true religion were greater in a multiconfessional society than in a confessional one. Imagine, he said, a man suffering from a 'deadly disease', for which there are twenty possible remedies, only one of which is effectual. If the man has access to just one possible cure, his chances of recovery are twenty to one. But if he is able to experiment with all the remedies, his odds of finding the right one are significantly higher. So it is with religion. In Roman Catholic Spain or Lutheran Germany, one has access to just one possible remedy. But in Holland, all the options are available. Suppose that a Turk comes to Amsterdam, seeking Christian truth. Here he 'informes himself fully of them all and at last fixes upon one'. He may, given the human 'propensity to evill', make the wrong choice. But he will at least have encountered the true religion, and made an 'examination or triall' of the alternatives. In most countries, by contrast, the people are 'only suffered to be instructed in the Country Religion (be it good or bad)', and they take up 'a Religion at hap hazard'. Better to live in Amsterdam, than in Rome. ${ }^{70}$ Gamblers say that it is better to 'lose their own money, then that others should lose it for them', and in the case of souls, we would 'quickly chuse to hazard the losse of our own souls our selves', rather than take a chance on the judgement of someone else. ${ }^{71}$

Robinson's probabilistic approach to the salvific prospects of individuals was couched within a wider missionary argument for multiconfessionalism. Dutch toleration advanced the Gospel; the 'execrable tyranny and dominion' of the Papacy in Italy and Spain retarded it. The early Christians had been able to spread their Gospel freely across national boundaries thanks to the pax Romana. Modern Protestants, however, had made little effort to take the Gospel to 'Infidells and Hereticks' in their own lands, nor had they 'allured them to come unto us'. ${ }^{72}$ Yet Christians had a duty to 'preach the Gospel unto all Nations' (Matt 28:19), and this could only be done when Reformed Protestants debated freely with Papists and Turks without fear of persecution. 'This combat', Robinson explained, 'must be fought out upon eaven ground, on equall termes, neither side must expect to have greater liberty of speech, writing, Printing, or whatsoever else, then the other'. Protestants would never fulfil Christ's missionary mandate until they lived among other peoples and tolerated other faiths. The 'maximes of persecution' prevented Christians from fulfilling Christ's commission. ${ }^{73}$ Robinson the godly merchant wanted to see the removal of the protectionist barriers erected by confessional states. His vision of free trade in religion, of a competition for hearts and minds 'fought out upon eaven ground, on equall termes', was remarkably bold, though it has more in common with the strategy of later Protestant missionary movements than with the modern secular liberalism. ${ }^{74}$

\footnotetext{
${ }^{69}$ Marchamont Nedham, The Case of the Commonwealth Stated (1650), pp. 98-99.

${ }^{70}$ [Robinson], John the Baptist, pp. 84-85.

${ }^{71}$ [Robinson], Liberty of Conscience, p. 41.

72 [Robinson], John the Baptist, p. 44, 6-7.

73 [Robinson], Liberty of Conscience, pp. 17-21.

${ }^{74}$ On later efforts to promote 'free passage' of the Protestant Gospel see Todd Thompson, 'The Evangelical Alliance, religious liberty, and the Evangelical conscience in nineteenth-century Britain', Journal of Religious History, 33 (2009), 49-65.
} 


\section{Catholic Tolerationists}

The arguments and examples used by radical Protestant tolerationists were ripe for exploitation by members of England's Catholic minority. Many Independents (including Milton) refused to extend toleration to Catholics, citing both their idolatry and their loyalty to a foreign power. ${ }^{75}$ But some did envisage toleration for peaceable Catholics. ${ }^{76} \mathrm{~A}$ number of Catholic writers posed as Independents and pushed the logic of the tolerationist argument towards Catholic toleration. ${ }^{77}$ The example of Europe's multiconfessional polities served their purposes. A New Petition of the Papists (1641) has been attributed to William Walwyn, but it could be a Catholic tract. It suggested a new law imposing penalties on those who 'affront or upbraid the other for his Religion'. This was already the policy in 'divers well governed Countries', such as 'Holland, Germanie, France and Polonia'. ${ }^{78}$ In 1649, another advocate of toleration for Catholics used the same examples. Introducing himself as a supporter of the Levellers' Agreement of the People, he argued that the liberty of conscience it promised should include Catholics. After all, in France, Holland, Germany and Switzerland, 'persons of all Religions are indifferently employed and found faithfull in Offices and Places of greatest trust' ${ }^{79}$

In The Christian Moderator: Or Persecution for Religion Condemned (1651), the Catholic John Austin also ventriloquised a radical Protestant voice, but he displayed a more detailed knowledge of the practice of European multiconfessionalism. In Switzerland there was a 'union of hearts, and common interests of State, between the Protestant and Catholike Cantons':

...very many Churches serve by turns upon the same day, for the exercise of both Religions, dividing every Sunday morning into two parts, and assigning to each about three hours for their devotions, wherein they are so punctuall to maintain equality, that if the Protestants have the first three hours one morning, next week they are to have the Last; and this they continually practise, without enterfering or offending one another. ${ }^{80}$

Austin continued by noting that 'in many Provinces, and free Towns in Germany', adherents of different confessions displayed 'fair comportment' towards one another'. But the 'most remarkable' case was that of Holland. Even during the long struggle against Spain, 'the States (then whom none are more vigilant over their true Interest) have not only with security, but exceeding benefit to their Common-wealth, tolerated the Catholikes of quiet Conversation, to live freely amongst them'. As a

\footnotetext{
${ }^{75}$ For the most recent discussion see Andrew Hadfield, 'Milton and Catholicism', in Achinstein and Sauer, eds, Milton and Toleration, ch. 10.

${ }^{76}$ See N. Carlin, 'Toleration for Catholics in the Puritan Revolution', in Ole Grell and Robert Scribner, eds, Tolerance and Intolerance in the European Reformation (Cambridge: CUP, 1996), pp. 216-30; John Coffey, 'Puritanism and liberty revisited: the case for toleration in the English Revolution', Historical Journal, 41 (1998), pp. 961-85.

${ }^{77}$ Several of these writers (including John Austin) belonged to the idiosyncratic Catholic circle gathered around Thomas White (alias Blacklo). See Jeffrey R. Collins, 'Thomas Hobbes and the Blackloist conspiracy of 1649', Historical Journal, 45 (2002), 305-31.

${ }_{79}^{78}$ A New Petition of the Papists (1649), in The Writings of William Walwyn, p. 57.

${ }^{79}$ No Papist, No Presbyterian (1649), pp. 1-2, 4.

${ }^{80}$ William Birchley [i.e. John Austin], The Christian Moderator, or Persecution for Religion Condemned (1651), p. 16.The practice of sharing churches is vividly illuminated in Kaplan, Divided by Faith, pp. 198-217.
} 
result, the Catholics, 'in gratitude for so favourable a treating, have exactly corresponded to the mercy of their magistrates, with a most, constant, sincere, and faithfull obedience' ${ }^{81}$

When Austin (in his Protestant guise) compared continental arrangements to the case of the English recusants, he was struck by the stark contrast and 'the unreasonablenesse of our persecution'. If the Swiss and the Germans and the Dutch could accommodate religious difference, why not the English? Christians, Jews and Turks were 'opposite in belief', 'yet we see by experience that Jews are not inconsistent with the Government of Christians, nor Christians with that of the Turks, no not such Christians as are here in question, Papists'. In France, 'the Papists themselves...outgo us in their tender and moderate behaviour towards the Protestants of their Country, notwithstanding former provocations to jealousie in the last civil wars, nay notwithstanding present provocations by our severity against all of their profession in England'. Austin himself had attended many conferences in Paris, where clergy and tradesmen of different confessions 'freely defended' their own opinions, without fear and 'with a courteous friendliness and mutuall compassion'. He had often thought that this was a French fashion worth importing into England. Furthermore, the French King allowed 'a certain number of publike Churches to Proestants, and as much liberty in private for the exercise of their consciences as any disagreers from the common belief of the State can reasonably desire'. Even the Spanish Inquisition, '(so universally abhor'd) practices all imaginable means towards the accused, to reduce his judgement to theirs, before they pronounce theirs against him, and upon the conformity immediately acquit him'. The English might 'cry up Liberty of Conscience', but they still had a lot to learn from their European neighbours. Yet there was hope - the Presbyterians, those 'cruell torturers of the Conscience' had been defeated, and under its new Independent rulers, England might yet enact 'a generall Act of Conscience-Indemnity'. ${ }^{82}$

In the politically chaotic year of 1659 following Oliver Cromwell's death, Catholic pamphleteers once again tried to foster sympathy for their co-religionists by posing as radical Independents and pointing to European multiconfessionalism. One writer noted that the Kings of France and Poland entrusted high military office to Protestants, a policy that evoked gratitude and loyalty among the tolerated minority. English persecution of Catholics, he claimed, had 'made us an obloquy to all our neighbours, even to our brethren the Hollanders, whose Christian policy even beyond envy flourisheth at Amsterdam, and other places, with exemplar piety and freedom' ${ }^{83}$ Another pamphleteer observed that religious coercion had been condemned by Catholic monarchs like King Stephen the Wise of Poland, the King of Bohemia, the Emperor Charles V, and King Henry III and IV of France. English regimes, however, could be worse than 'the Spanish Inquisition it self, which we esteem so odious'. English merchants in Spain were not 'molested or troubled by the Inquisition' (unless for public disorder), and it had even banished Spaniards who abused Englishmen as heretics. It was the shame of the English that they had been 'overwitted by the Hollanders, whom yet we consider inferior to us'. Although the large Catholic minority in the Netherlands did not enjoy 'the publick exercise of their Religion, (which is granted to diverse other professions), but rather a connivance of private exercise', they had proved 'most faithful' to the state, and served it even against a Catholic prince. The 'prudent moderation' of the Dutch had 'setled and maintained their Republick, raising it almost from nothing to a great height and perfection'. The English, however,

\footnotetext{
${ }^{81}$ [Austin], The Christian Moderator, pp. 16.

82 [Austin], The Christian Moderator, pp. 17, 25-26.

${ }^{83}$ T.F., Philanthropia, or a holding forth of Universall immunitie in exercise of Christian Religion (1659), p. 5.
} 
could settle nothing because they insisted on 'persecuting one Another for Religion', which 'put the State always a rolling'. They had much to learn from the Dutch model. ${ }^{84}$

\section{Jewish Readmission}

Besides proving useful to English Catholics, the Dutch example also served the cause of Jewish readmission. Jews had been expelled from medieval England, and the country still had no open Jewish community when the Amsterdam rabbi Menasseh ben Israel formally petitioned Cromwell and his Council of State about readmission. ${ }^{85}$ Among his contacts were philo-semitic Puritan millenarians like the ecumenist John Dury and the Baptist pastor Henry Jessey. ${ }^{86}$ These figures expected the imminent conversion of the Jews as a prelude to the coming rule of Christ, and believed that it would be hastened if Protestant nations followed the Dutch by allowing the Jews to reside among them. Jewish merchants, for their part, hoped to have as much freedom of worship and trade in London 'as they enjoy in Holland, and did enjoy in Poland, Prussia and other places'. ${ }^{87}$

Jessey thought it a scandal that the Jews were tolerated by the Pope, the Duke of Florence, the Ottomans and 'Barbarians', but not by the English, who could expose them to the Gospel. ${ }^{88}$ Another defender of readmission agreed:

We finde Hungaria entertains them, Germany harbours them, Poland till these wars, and Sweden trades with them, Denmark affords them habitation and Synagogues, Italy loves them, Holland approves them, Hamburgh, Lubeck, most of the Imperial Hans-towns invite them In; and yet in all these Countries and places, who admit them, there is no disturbance in Government, no Civil or Inbred Commotions, no popular Insurrections against the Magistrates, about the Admission of the Jews, nor any the least offence taken at the Jew, but live quietly and peaceably together, the Magistrate protecting, and the Jews obeying his Orders and Injunctions. ${ }^{89}$

When Cromwell convened a conference to discuss readmission at Whitehall, it produced protracted debate and no consensus. Jewish readmission was opposed by some English merchants and by antitolerationist Puritans like William Prynne. Yet the episode did reveal the presence of an underground Sephardic community in London, and its informal recognition. Once again, English tolerationists had used European examples to imagine a world beyond the confessional state.

\footnotetext{
${ }^{84}$ England's Settlement upon the Two Solid Foundations of the Peoples Civil and Religious Liberties (1659), pp. 21-23, 30-32.

${ }^{85}$ See David S. Katz, Philo-Semitism and the Readmission of the Jews to England, 1603-1655 (Oxford: Clarendon Press, 1982); David S. Katz, The Jews in the History of England, 1485-1850 (Oxford: Clarendon Press, 1994), pp. 107-40; Eliane Glaser, Judaism without Jews: Philosemitism and Christian Polemic in Early Modern England (Houndmills: Palgrave, 2007).

${ }^{86}$ See Yosef Kaplan, Henry Mechoulan and Richard H. Popkin, eds, Mennasseh ben Israel and his World (Leiden: E. J. Brill, 1989); Ernestine G. van der Wall, 'A philo-semitic millenarian on the reconciliation of Jews and Christians: Henry Jessey and his "The glory and salvation of Judah and Israel”', in David S. Katz and Jonathan I. Israel, eds, Sceptics, Millenarians and Jews (Leiden: E. J. Brill, 1990), pp. 161-84.

${ }^{87}$ Henry Jessey, A Narrative of the late Proceeds at White-hall, concerning the Jews (1656), p. 10.

${ }^{88}$ Jessey, A Narrative, p. 11.

${ }^{89}$ D.L., Israels Condition and Cause Pleaded, or Some Arguments for the Jews Admission into England (1656), pp. 40-41. The same argument is made by reference to the Dutch experience in Thomas Collier, A Brief Answer to some of the Objections and Demurs made against the Coming in and inhabiting of the Jews in this Commonwealth (1656), p. 10.
} 


\section{Anti-tolerationists}

That vision, of course, was shared by only a minority, and it was fiercely opposed by many of the godly. But opponents of toleration were no more parochial than their rivals. Both Scottish and English Presbyterians had well established contacts with Dutch Reformed divines and with expatriate Presbyterian communities. The English heresiographer Thomas Edwards would end his days (ironically) in the pluralistic city of Amsterdam, where he was hosted by a staunchly Presbyterian English church. He had already exploited his Dutch contacts in order to investigate the activity of congregationalist exiles in the 1630s. ${ }^{90}$ The militant Covenanter Samuel Rutherford was offered chairs at the universities of Franeker and Utrecht, and Robert Baillie, another fierce Covenanter critic of the Independents, kept up a regular correspondence with his cousin who lived in the Netherlands.

Anti-tolerationists claimed that radical Independents were citing Dutch precedent in order to go beyond it. Baillie informed his cousin that some of the Independent party were 'openly for a full libertie of conscience to all sects, even Turks, Jews, Papists, and all to be more openly tolerate than with yow' ${ }^{91}$ On Baillie's account, radical Independents were abusing the Dutch model, hiding its limits and their own ambitions:

Not only they praise your magistrate, who for policie gives some secret tolerance to diverse religions, wherein, as I conceave, your divines preaches against them as great sinners; but avows, that by God's command, the magistrate is discharged to put the least discourtesie on any man, Turk, Jew, Papist, Socinian, or whatever, for his religion. ${ }^{92}$

As these quotations suggest, anti-tolerationists could exploit the limits of Dutch tolerance. Thomas Edwards argued that the successful containment of the Dutch Arminians demonstrated that magistrates could suppress heresies, recover 'many souls', and settle 'the peace of Churches and States'. He and other Presbyterians knew that orthodox Dutch Reformed clergy were critical of the lax policy of their regents. Franciscus Junius and Gisbertus Voetius could be cited in support of conventional Calvinist teaching on the religious duties of secular magistrates. ${ }^{93}$ And in Gangraena, Edwards printed a letter from a Dutch divine lamenting the spread of sectarianism and heterodoxy in England and highlighting the restrictions on them in the Netherlands:

O blessed holy Holland, righteous Amsterdam, heretofore accounted the sink of Errours and Heresies, but now justified by London. With us are punished with banishment, or piercing through the tong with a hot Iron, those that but slanderously speak of the Virgin Mary: Here we burne the books of the Socinians Errours, and they may not with knowledge be sold in these parts: Here indeed every one is left to enjoy the freedome of his Conscience in his own Family, but to keep Conventicles and meetings of divers Families together, Amsterdam it selfe will not suffer, except in Anabaptists, Lutherans, and Remonstrants. At London is taught Blasphemy against Christ, God, his Word, Worship, and Sacraments, by Enthusiasts,

\footnotetext{
${ }^{90}$ See Ann Hughes, Gangraena and the Struggle for the English Revolution (Oxford: OUP, 2004), pp. 1-2; Thomas Edwards, Antapologia (1644) and Gangraena (1646).

${ }^{91}$ Robert Baillie, Letters and Journals, ed. D. Laing, 3 vols (Edinburgh, 1841-42), ii.181.

${ }^{92}$ Baillie, Letters and Journals, ii. 184.

93 Thomas Edwards, The Casting Down of the Last and Strongest Hold of Satan, or a Treatise against Toleration (1647), pp. 56, 185-86.
} 
Antinomians, Libertines, and Seekers: There the Socinian tricks are new moulded, there all Sects and Hereticks may keep their separated, publike and secret Conventicles. Whence is it that you are so suddenly led away unto another Gospell? ${ }^{94}$

If Dutch practice could be used to counter radical Independents, it was still an embarrassment to critics of toleration. They preferred to look to Geneva. Even a conservative Congregationalist could note that 'the Church and Religion doth prosper better in Geneva and its territory and among the Helevetian Protestants, where one way of true Religion is maintained, than in Polonia, such States wherein this mingle-mangle is tolerated'.$^{95}$ Less surprisingly, Presbyterians praised Geneva, which 'hath Lawes against Hereticks and other false teachers, and have put some Hereticks and Blasphemers to death, as Servetus and others, as is well knowne to those that know any thing of our latter times'. If other Reformed churches or states had not enacted similar laws, 'they are and have been faulty'. ${ }^{96}$

Toleration was depicted as a Dutch error - promoted by Anabaptists and Arminians like Hugo Grotius and Simon Episcopius. Rutherford defined 'Arminian liberty of conscience' as the view 'that men in a Christian Commonwealth, may be of any Religion, and the magistrate is to behold men as an indifferent spectator, not caring what religion they bee of, whether they be Papists, Jewes, Pagans, Anabaptists, Socinians, Macedonians'. ${ }^{97}$ Another Covenanter, George Gillespie, complained that toleration was promoted by 'the Socinians, Arminians and Anabaptists', but 'constantly opposed by all that were sound and orthodoxe, both Ancient and Moderne'. Sadly, 'in Germany, France, Holland, Poland, yea under the Turkish Tyranny, contrary religions, and opposite persuasions and practises, have been, and are tolerated upon State-principles' ${ }^{98}$ Thomas Edwards warned that the Dutch Arminians 'at first desired but a toleration.... but afterwards that by the connivance and favour of the Magistrates they were in some Cities and places (as Amsterdam \&c.) grown to a great number, and had a great power, then they would not...tolerate the orthodox Ministers, but persecuted them...' English Independents, like the German Anabaptist and Dutch Arminians before them, would use toleration as a stepping stone to repression. ${ }^{99}$

Dutch pluralism haunted the imagination of anti-tolerationists. As early as 1641 , during a moral panic over the swarm of sectaries, one writer claimed that London was being 'Amsterdamnified by severall opinions' ${ }^{100} \mathrm{~A}$ royalist pamphleteer, shocked by the recent publication of the Koran in English translation, warned that if the Independents had their way, England would soon have 'a Medley of Religions'. 'Amsterdam must be beholding to us, as we have been formerly to them, for new Opinions' ${ }^{101}$ Theophilus Brabourne offered a curt reply to tolerationists: 'Why should you make Holland a president for us in this respect? Are they not the reproach of the world, for maintaining all

\footnotetext{
${ }^{94}$ Edwards, The Second Part of Gangraena (1646), p. 165.

${ }^{95}$ A Censure of that Reverend and Learned Man of God Mr John Cotton (1656), p. 8.

${ }^{96}$ A Vindication of a Printed Paper (1646), p. 22.

${ }^{97}$ See Rutherford, A Free Disputation, pp. 216-17, 355. See also Prynne, The Sword of the Christian Magistrate Supported (1653), p. 159.

98 [George Gillespie], A Late Dialogue betwixt a Civilian and a Divine (1644), pp. 32, 30.

${ }^{99}$ Edwards, Antapologia (1644), pp. 279-80.

${ }^{100}$ Religions Enemies (1641), p. 6. On the moral panic of 1641 see David Cressy, England on Edge: Crisis and Revolution, 1640-42 (Oxford: OUP, 2006), ch. 10.

101 [Dr Richard Holdsworth?], An Answer without a Question: or the Late Schismaticall Petition for a

Diabolicall Toleration of Seuerall Religions Expounded (1649), p. 6.
} 
Religions, men say, if a man hath lost his Religion, he may find it in Amsterdam. Let the practise of the Prophets and Apostles be our president, and not Holland' ${ }^{102}$

In Englands Metamorphosis, or a Dialogue between London and Amsterdam (1647), the parallels between the two cities were fully developed. London addressed the Dutch town with gushing admiration: 'Be thou my president; are not within thee a mixt multitude of severall nations, worshippers of the true God, of Mahomet, and of no God; and these occasion no garboiles in thee...they tosse not each others limbs on the swords of their tongues, nor damn each other with invective oratory, even to the profoundity of abysse'. Amsterdam confirmed this report, explaining that her tranquil pluralism was due to the absence of bigoted Presbyterians. London expressed wonder at Amsterdam's 'order in the midst of disorder', and the two rejoiced at London's metamorphosis. Amsterdam would no longer need to function as a 'city of refuge' for the 'thronging Sectaries' expelled from England. They could now flourish at home. Amsterdam admitted that she was 'wholly estranged from God', and had gone whoring after idols. The two cities were like Judah and Samaria, sisters in apostasy. The dialogue ended with a poetic warning that lamented the sectarian fragmentation chronicled in Edwards' Gangraena:

Amazed and amated much I am, To see this Kingdome turn'd to Amsterdam; Six years agoe we had of Sects fourscore, Which are increast now to one hundred more... ${ }^{103}$

Amsterdam was also denounced by opponents of the readmission of the Jews. William Hughes declared that 'Reason of State makes the Dutch-men tolerate all Religions but the Popish. From whence shall it not presently be concluded, that all their neighbours should do the like'. ${ }^{104}$ William Prynne poured cold water on the millenarian dreams of Jewish conversion - 'learned able Protestant Divines in Holland, Germany, France, Denmarke' had been unable to convert the Jews, so 'what hopes have we to do it?' ${ }^{105}$ For most English Puritans, going Dutch had limited appeal.

\section{Conclusion}

Yet if the English remained largely sceptical about European models, the toleration controversy had expanded horizons and placed a question mark against Anglo-centric complacency. Contemporary cases of multiconfessionalism were not at the heart of the dispute, but they had been widely invoked and debated. It is difficult to assess the impact of this debate on English attitudes and practice. W. K. Jordan was being wildly optimistic when he claimed that by 1660 the necessity of toleration was accepted by 'responsible opinion' and 'the mass of men'. ${ }^{106}$ More recent historians tend towards the opposite extreme. It does seem clear that tolerationist theory had not fundamentally shifted public opinion. In 1659, the well-connected young Independent Henry Stubbe

\footnotetext{
102 Theophilus Brabourne, The Second Part of the Change of Church Discipline (1654), p. 63.

${ }^{103}$ Englands Metamorphosis, or a Dialogue between London and Amsterdam (1647), pp. 1-2, 6.

${ }^{104}$ William Hughes, Anglo-Judaeus, or the History of the Jews, whilst here in England (1656), sig. Fiir.

${ }^{105}$ William Prynne, A Short Demurrer to the Jews (1656), p. 110.

106 Jordan, The Development of Religious Toleration, IV, pp. 9, 467.
} 
declared that 'Those who are for a free Toleration are the lesse numerous, beyond all proportion' ${ }^{107}$ The developments of the 1660 s support his assessment.

We can be more confident about the impact of practice on theory. For some individuals, the example of peaceful religious coexistence overseas assisted their intellectual shift away from the Augustinian defence of religious coercion. Tolerationists like Henry Robinson, Richard Overton, Roger Williams and John Austin had witnessed inter-confessional and even inter-faith cooperation in the Netherlands, France and America, and this was clearly a factor in their thinking, perhaps a decisive one. Yet even though these writers recognised the political origins of religious liberty, their own texts laid relatively little weight on continental case studies. They chose to fight for toleration on the high ground of moral and religious principle, not on the low ground of 'worldly policie' and 'State necessitie'. That may have been naïve. But perhaps they were right to think, like Locke and Bayle after them, that (in the final analysis) the legitimacy of religious coercion could only be subverted by normative considerations.

${ }^{107}$ Stubbe, An Essay in Defence of the Good Old Cause (1659), sig. **8v-**8r. 